Are the living collections of the world's botanical gardens

following species-richness patterns observed in natural ecosystems?

Journal Article

Author(s):

Pautasso, Marco; Parmentier, Ingrid

Publication date:

2007-06

Permanent link:

https://doi.org/10.3929/ethz-b-000066890

Rights / license:

In Copyright - Non-Commercial Use Permitted

Originally published in:

Botanica Helvetica 117(1), https://doi.org/10.1007/s00035-007-0786-y 


\title{
Are the living collections of the world's botanical gardens following species-richness patterns observed in natural ecosystems?
}

\author{
Marco Pautasso $^{1,2}$ and Ingrid Parmentier ${ }^{3,4}$ \\ ${ }^{1}$ Division of Biology, Imperial College London, Wye Campus, High Street, Wye, Kent, TN25 \\ 5AH, United Kingdom; e-mail: m.pautasso@ic.ac.uk \\ 2 Institute of Integrative Biology, Department Umweltwissenschaften, ETH, CH-8092 Zürich \\ ${ }^{3}$ Laboratoire de Botanique systématique et de Phytosociologie, CP 169, Université Libre de \\ Bruxelles, 50 Av. F. D. Roosevelt, 1050 Bruxelles, Belgique \\ ${ }^{4}$ Oxford University Centre for the Environment, University of Oxford, South Parks Road, \\ OX1 3QY, United Kingdom
}

Manuscript accepted 19 February 2007

\begin{abstract}
Pautasso M. and Parmentier I. 2007. Are the living collections of the world's botanical gardens following species-richness patterns observed in natural ecosystems? Bot. Helv. 117: $15-28$.

Botanical gardens aim to promote the awareness, study and conservation of plant species diversity, but little is known about the species diversity of botanical gardens themselves. We therefore investigated whether the species richness of the world's botanical gardens is related to their size, age and geographical location by compiling data from gardens in 124 different countries. The data show that even in these highly managed ecosystems, species richness can be described in terms of a relatively small number of large-scale patterns. As with most natural ecosystems, there were positive species-area and species-age relationships. There was also a positive latitudinal gradient in species richness, which contrasts with the trend observed in natural ecosystems. This discrepancy may be due to the use of heated greenhouses at high latitudes, the rarity of old botanical gardens in the tropics, and the problem of poverty in developing countries, where most hotspots of plant biodiversity are located. There is thus a need to allocate more funds to botanical gardens in species-rich regions. This study also calls for an increase in the coordination of data management between botanical gardens.
\end{abstract}

Key words: Ex-situ conservation, global priorities, metapopulation network, scale, spatial autocorrelation, species-energy. 


\section{Introduction}

Botanical gardens aim to increase the awareness, investigation and conservation of plant species diversity (Ingram 1992; Frankel et al. 1995; Wyse Jackson 1999; Leadlay et al. 2006). Today there are ca. 2500 botanic gardens in 156 countries, with over 6 million accessions of living plants, and approximately 80000 taxa in cultivation (the estimated number of vascular plant species in the world is only roughly three times that figure; Wyse Jackson 2001). In this way, the world's botanical gardens have become unmatched collections of biodiversity (Heywood 1990; Maunder 1994; Marris 2006). In the richest botanical gardens, more than ten thousand plant species are displayed over areas of only a few tens of hectares. Even botanical gardens around one hectare large can exhibit similarly high species richness. The species richness per unit area of botanical gardens is much higher than the average one in their surroundings (Heyd 2006). This is particularly striking in species-poor regions at temperate and boreal latitudes, but also applies to the tropics. Indeed, even if hundreds of plant and tree species can be found in a single hectare of rain forest (Leigh et al. 2004; Novotny et al. 2004), tropical botanical gardens can exhibit thousands of species. This prompts the question of which factors mainly control variations in the species richness of botanical gardens throughout the world.

Ecologists and biogeographers have investigated large-scale patterns in species richness of many natural ecosystems. Three of the main explaining factors of species richness in natural ecosystems are (i) the species-area relationship (Connor and McCoy 1979; Lawton 1999), (ii) the species-age relationship (Halpern and Spies 1995; Guariguata et al.1997; Pärtel and Zobel 1999), and (iii) the species-productivity relationship (Currie 1991; Waide et al. 1999; Gaston 2000). The first pattern states that species richness increases with the area of the studied habitat. The second follows from studies of ecological successions and species-rich old-growth habitats. The third explains the decreasing species-richness gradient with increasing latitude. Although there has been a recent increase in the interest of macroecologists and biogeographers in ecosystems modified by human beings (Gaston 2004; Terrell 2006), we do not know whether and how far these determinants of the diversity of natural ecosystems also apply to highly managed habitats such as botanical gardens. Here are the main questions addressed in this paper:

- Is there a relationship between the species richness of a botanical garden and its area? The positive species-area relationship is one of the oldest and best documented patterns in community ecology (Connor and McCoy 1979; Crawley and Harral 2001). But botanical gardens are mostly artificial ecosystems where the presence and location of most plants is the result of a gardener's decision. Larger gardens may be able to support more species than smaller ones, or may only increase the number of individuals of the same species or fill the space with e.g. recreation areas, natural vegetation, information displays, molecular laboratories, and seed banks.

- Is there a relationship between the species richness of a botanical garden and its age? Botanical gardens can be thought as the longest-running experiments in plant ecology in the world (Tomasi 2005; Heyd 2006). The oldest botanical gardens existing were established as collections of medicinal plants during the late Renaissance in Italian (Pisa, 1544; Padua, 1545; Florence, 1555; Bologna, 1568; Siena, 1588) and other European Universities (Jena, 1586; Leiden, 1587; Basel, 1589; Heidelberg, 1593; Montpellier, 1593). These may have had more time to accumulate plant species 
from the four corners of the world than gardens of recent foundation. But the species richness of younger gardens may have reached or surpassed the one of older gardens due to a smaller size of plant and tree specimens, more space to house living collections, larger financial and human resources or a better spatial arrangement of the collections.

- Is there a latitudinal gradient in the species richness of botanical gardens? A decrease of their species richness with absolute latitude would be expected given the generality of that pattern in natural ecosystems (Rohde 1992; Gaston 2000; Hillebrand 2004), and given that botanical gardens in the tropics have in most cases a larger pool of species in the surrounding region from which to collect plants (Myers 1988; Scheiner and Rey-Benayas 1994; Kier et al. 2005). However, the purchase of seeds from other regions may be a limiting factor in poor countries, although the international system of seeds exchange through the seed catalogues of botanical gardens (Index Seminum) is a relatively cheap way to obtain propagating material and involves also tropical countries. But the gradient may be cancelled out by the location at high latitude of many important botanical gardens which can afford to grow plants originating from warmer regions in glasshouses.

This analysis provides an opportunity to ascertain some general large-scale patterns in the species richness of botanical gardens and to discuss how these may develop in the future.

\section{Materials and Methods}

Botanical Garden Conservation International (BGCI) provides on its website (http://www.bgci.org/) the addresses of ca. 2500 botanical gardens. A substantial proportion of these are arboreta, which were not included in these analyses. Data from 704 botanical gardens were retrieved from publications and web-pages. Recorded data were: (i) species richness of the living collections, (ii) total area of the garden, (iii) year of establishment, and (iv) geographical coordinates. To fill the gaps in the database, we sent 292 emails and 209 letters at the beginning of 2006 and obtained respectively 127 and 33 replies.

The compiled database is therefore not complete but it should be comprehensive enough to establish general patterns. Data come from 124 different countries but nearly the majority of the botanical gardens in the database are European (45\%) and half of them are located in only ten countries (Tab. 1). Not all fields of interest could be filled for each botanical garden $(n=242,468$, and 624 for species richness, area, and year of establishment, respectively). For an additional 130 gardens, we obtained information on the number of taxa, i.e. including cultivars, forms and varieties. When a botanical garden had been enlarged during the course of its history, its current size was recorded as its area. When a botanical garden had been moved to a different location, the year of establishment was dropped in favour of the year of the opening at the new location.

Species richness, area and age were log-transformed before analysis to conform to the assumptions of statistical methods. The logarithm of age (in years, as of 2006) instead of the logarithm of the year of establishment was used because the latter was not normally distributed. Analyses were run in SAS 9.1. Mixed models with exponential covariance structure were used to test the null hypotheses described above controlling for spatial autocorrelation (Pautasso and Gaston 2006). Results from spatial and non- 
Tab. 1. Total number of botanical gardens (including arboreta, according to BGCI and as of 2006 , Tot $=2547)$ and for the botanical gardens included in this study: number of botanical gardens $(\mathrm{N}=704)$, minimum and maximum specific (and not taxonomic) richness, minimum and maximum area (in ha), first and last year of establishment. This information is given for Switzerland, the ten countries with the highest number of botanical gardens in the database analyzed and other countries.

\begin{tabular}{lrrrrrrrr}
\hline Country & Tot & N & $\begin{array}{c}\text { Spp } \\
\text { min }\end{array}$ & $\begin{array}{l}\text { Spp } \\
\max \end{array}$ & $\begin{array}{l}\text { Area } \\
\text { min }\end{array}$ & $\begin{array}{l}\text { Area } \\
\text { max }\end{array}$ & $\begin{array}{l}\text { Year } \\
\text { oldest }\end{array}$ & $\begin{array}{c}\text { Year } \\
\text { youngest }\end{array}$ \\
\hline Australia & 129 & 35 & 200 & 10000 & 3.0 & 140 & 1816 & 2003 \\
China & 140 & 26 & 1000 & 10000 & 5.6 & 900 & 1871 & 1991 \\
France & 97 & 34 & 600 & 15000 & 0.3 & 237 & 1593 & 1999 \\
Germany & 104 & 47 & 700 & 22000 & 0.8 & 43 & 1586 & 1985 \\
India & 131 & 35 & 100 & 1000 & 6.5 & 22 & 1847 & 1996 \\
Italy & 104 & 28 & 400 & 12000 & 0.1 & 80 & 1544 & 1994 \\
Japan & 59 & 21 & 155 & 13000 & 3.0 & 59 & 1684 & 1980 \\
Russian Fed. & 110 & 26 & 1900 & 6000 & 2.6 & 170 & 1714 & 1974 \\
Switzerland & 24 & 14 & 600 & 8000 & 0.8 & 13 & 1589 & 1998 \\
UK & 106 & 40 & 80 & 12500 & 0.2 & 130 & 1621 & 2000 \\
USA & 370 & 62 & 600 & 17000 & 0.4 & 280 & 1842 & 2006 \\
Other Countries & 1173 & 322 & 120 & 16000 & 0.2 & 1681 & 1587 & 2003 \\
\hline
\end{tabular}

spatial models are generally consistent, but it is important to take into account the spatial non-independence of data (Kühn 2007). There may be spatial autocorrelation amongst botanical gardens in intensity of management, funding availability and other factors such as the relative importance of scientific vs. recreational use. Botanical gardens may be collaborating more with those in the same country than with those elsewhere, if only because of linguistic reasons. Moreover, even if many botanical gardens have glasshouses, in many cases climate is still a limiting factor for the living collections outside glasshouses and climate is spatially autocorrelated. Botanical gardens in e.g. California will tend to resemble each other more than those subject to the harsh winters of continental North America, because they can afford to keep many warm-loving species without protecting them from frost.

\section{Results}

\section{Species richness}

The species richness of the botanical gardens for which that information could be obtained ( $\mathrm{n}=242$; Fig. 1a) varies from 40 species in the Jardin Botanico Pillahuincó, of Bahia Blanca, Argentina (0.187 ha, founded in 2003) to 22000 in the Botanical Garden of Berlin, Germany (230 times larger and founded around 325 years before). Even higher numbers are attained by the Nikitsky Botanical Garden (Yalta, Ukraine), the Kew Gardens (London, UK), and the Auckland Botanical Gardens (New Zealand) with respectively 50000,30000 and 26000 taxa, but these numbers also include sub- 
specific divisions (throughout, unless specified, we refer to the number of species and not of taxa). The average species richness is roughly 4000, which is the species richness of the botanical gardens in Amsterdam, Netherlands (founded in 1638), Torino, Italy (1729), Rouen, France (1832), Braunschweig, Germany (1840), Poolewe, UK (1862), Sapporo, Japan (Hokkaido University, 1886), Wuhan, China (1956), Havana, Cuba (1968), and Decatur, Georgia, US (1990). The botanical garden of median species richness has roughly 2500 species. Estimates of the species richness of botanical gardens are usually approximations and often vary with the season. As figures frequently refer to previous years, they may be conservative, given that botanical gardens may increase their collections with time.

\section{Area}

The range of areas of the botanical gardens for which that information was obtained ( $n=468$; Fig. 1b) spans more than five orders of magnitude, varying from 0.14 ha (Orto Botanico of Bergamo, Italy, founded in 1972, with 900 species) to $16.8 \mathrm{~km}^{2}$ (Lancetilla Botanic Garden, Honduras, founded in 1925, no estimate of its species richness obtained). Altogether, the area of these 468 botanical gardens adds up to ca. $210 \mathrm{~km}^{2}$, i.e. slightly more than the area of the District of Columbia or of Liechtenstein. The average botanical garden is 45 ha large, which corresponds to the Alaska Botanical Garden in Anchorage (established in 1993, with 260 species), but also to the area of Vatican City or the administrative district of Oxford, UK. The botanical garden of median area is 12 ha large. It has to be noted that there are in the world at least three times more botanical gardens than the ones for which a measure of their area was collated here.

\section{Year of establishment}

The year of establishment of the botanical gardens in the compiled database $(\mathrm{n}=$ 624; Fig. 1c) varies from 1544 (Orto Botanico of Pisa, Italy; 3100 species in 3 ha) to 2006 (Western Pennsylvania Botanic Garden; work in progress, $178 \mathrm{ha}$ ). The average year of establishment is 1923, and the median is 1952, reflecting the fact that most botanical gardens were opened after the $2^{\text {nd }}$ World War. Only 10 botanical gardens were established before 1600 and are still located in the same place. This number doubled by 1690 , and doubled again by the year 1800. With the exception of the Koishikawa Gardens in Tokyo, all these botanical gardens were opened in Europe. In the course of the first half of the $19^{\text {th }}$ century, the number of botanical gardens doubled again with seven gardens founded outside Europe (Sydney, Australia, 1812; Bogor, Indonesia, 1817; Hobart, Tasmania, 1818; Peradeniya, Sri Lanka, 1821; Singapore, 1822; Washington, D.C., US, 1842; Ootacmund, India, 1847). It is likely that by 1850 colonial nations had established many other gardens outside Europe in order to investigate the possibility of introduction or exportation of crops and ornamental plants. But most of these gardens were not explicitly declared to be botanical gardens and managed as such. From the data available, there is evidence that the number of botanical gardens doubled again in the following fifty years, with at least thirty-one foundations outside Europe. Although these are conservative estimates, since for many botanical gardens we were not able to find out when they were established, there were at least 150 botanical gardens in the world in 1900, a number which approximately doubled by 1950, and by the turn of the millennium at least doubled again. 
(a)

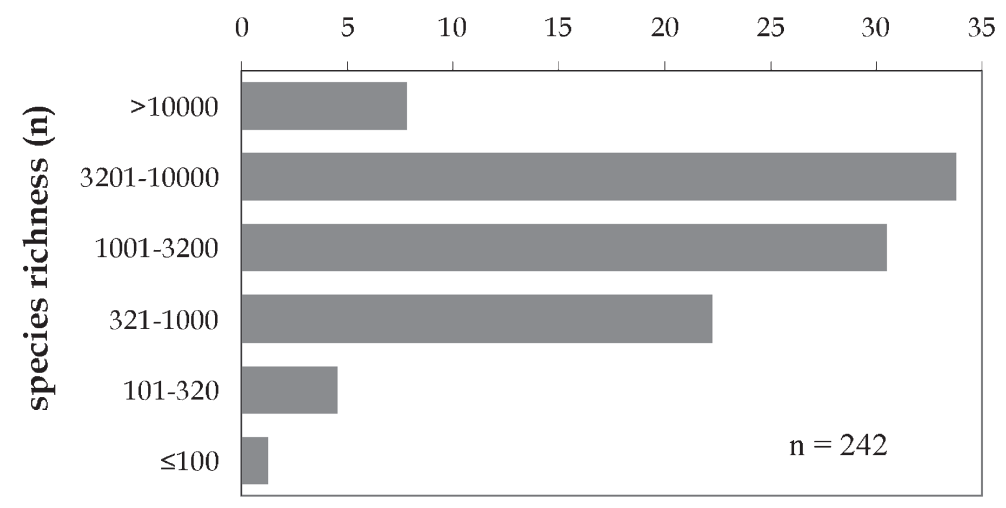

(b)

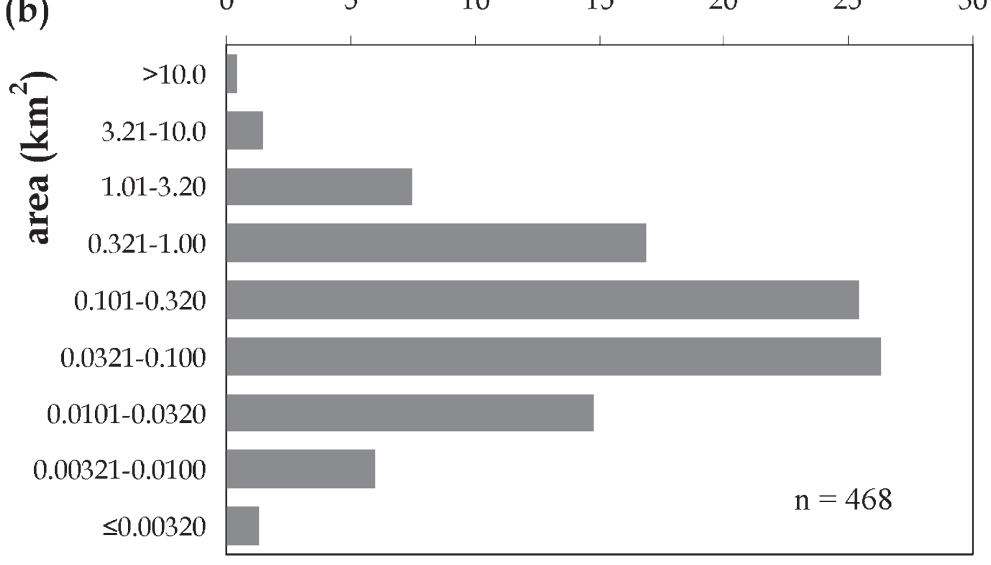

(c)

$\begin{array}{lllllll}0 & 10 & 20 & 30 & 40 & 50 & 60\end{array}$

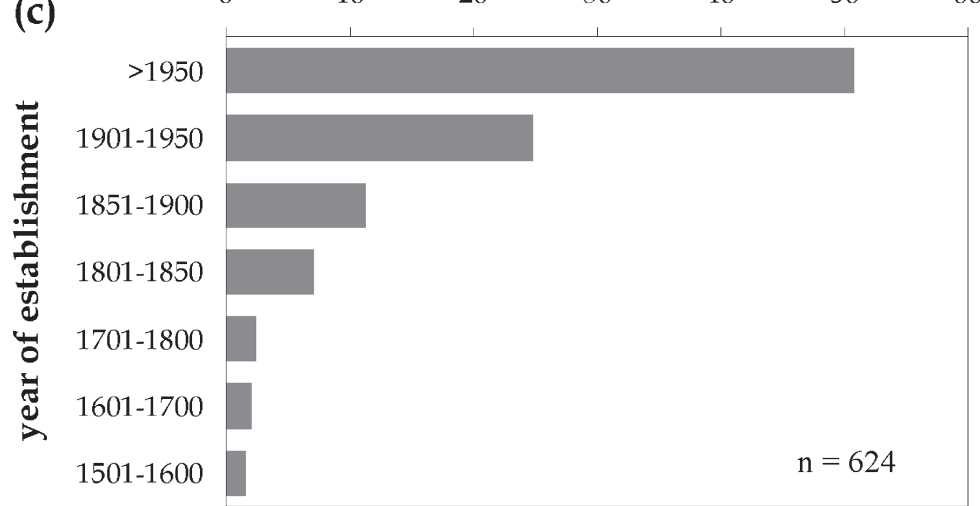

Fig. 1. Relative frequency distribution of the botanical gardens' (a) species richness, (b) area and (c) year of establishment. 


\section{Latitude}

The botanical gardens analyzed are located between $53^{\circ} \mathrm{S}$ (Carl Skottsberg Botanical Garden, at Punta Arenas in Argentina) and $70^{\circ} \mathrm{N}$ (Troms $\varnothing$ Botanical Garden, Norway). Only $15 \%$ of the botanical gardens in the database are to be found in the Southern Hemisphere. This is more than the proportion of the human world's population (ca. $11 \%$ ) but less than the one of the Earth's land area (ca. $30 \%$ ) located in the Southern Hemisphere. Moreover, the Austral hemisphere is home to many hotspots of plant biodiversity (e.g. Atlantic Brazil, South Africa, New Guinea, South-Western Australia). The proportion of botanical gardens in the database between the two Tropics is $20 \%$. The average absolute latitude of the botanical gardens analyzed is ca. $40^{\circ}$, the median is ca. $43^{\circ}$.

\section{Interrelationships}

Species richness significantly increases with increasing area (Fig. 2a) and with increasing age of botanical gardens (Fig. 2b). There is a marginally significant increase of species richness with absolute latitude (Fig. 3a). These three results (increasing species-area, -age, and -absolute latitude relationships) are robust when controlling for the other two factors in the model. For the 231 botanical gardens for which data on species richness, area and year of establishment were available, species richness significantly increases with garden area, age, and absolute latitude $\left(\mathrm{r}^{2}=0.39, \log (\mathrm{spp})=\right.$ $2.56+0.35 \log \left(\mathrm{km}^{2}\right)+0.35 \log ($ age $)+0.011 \mathrm{abs}($ lat $), \mathrm{p}=0.004$ for abs(lat) and $<0.0001$ for the other factors).
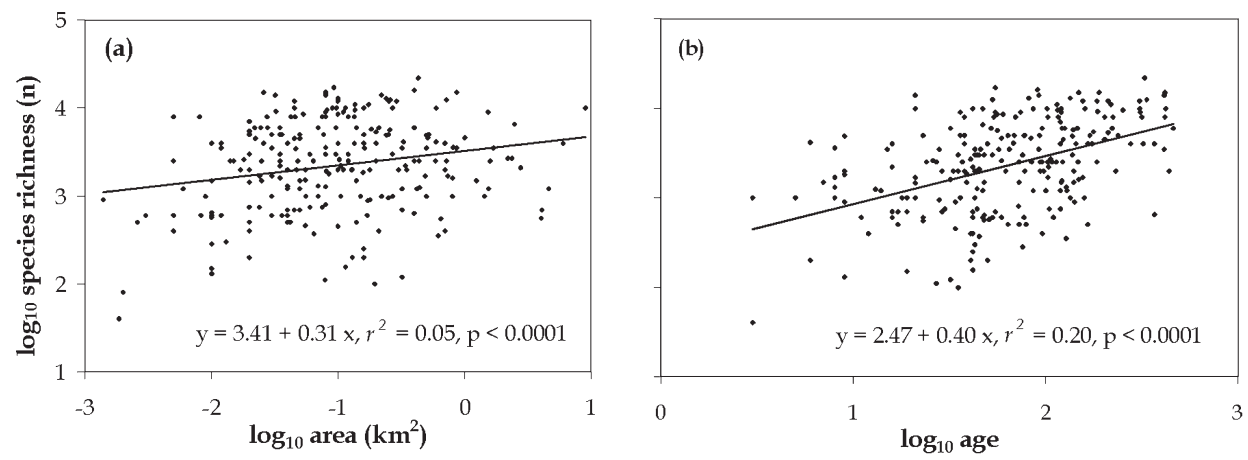

Fig. 2. Relationships between species richness and (a) area and (b) age (in years) of botanical gardens worldwide.

The generality of these results is corroborated by repeating the same analyses for an independent set of botanical gardens for which only an estimate of taxonomic (and not specific) diversity was obtained $(\mathrm{n}=121)$. The number of taxa increases with increasing area, age, and absolute latitude $\left(\mathrm{r}^{2}=0.22, \log (\operatorname{taxa})=3.29+0.34 \log \left(\mathrm{km}^{2}\right)+0.16\right.$ $\log ($ age $)+0.007$ abs(lat $), p$ resp. $<0.0001,=0.06$, and $=0.09)$, although only in a marginally significant way for age and absolute latitude.

For the botanical gardens for which an estimate of the specific (and not taxonomic) richness was available, the correlations between the explanatory variables are the 
following: there is a marginally significant decrease of the logarithm of area with absolute latitude (Fig. 3b), no significant variation of area with age (Fig. 4a) and of absolute latitude with age (Fig. 4b).
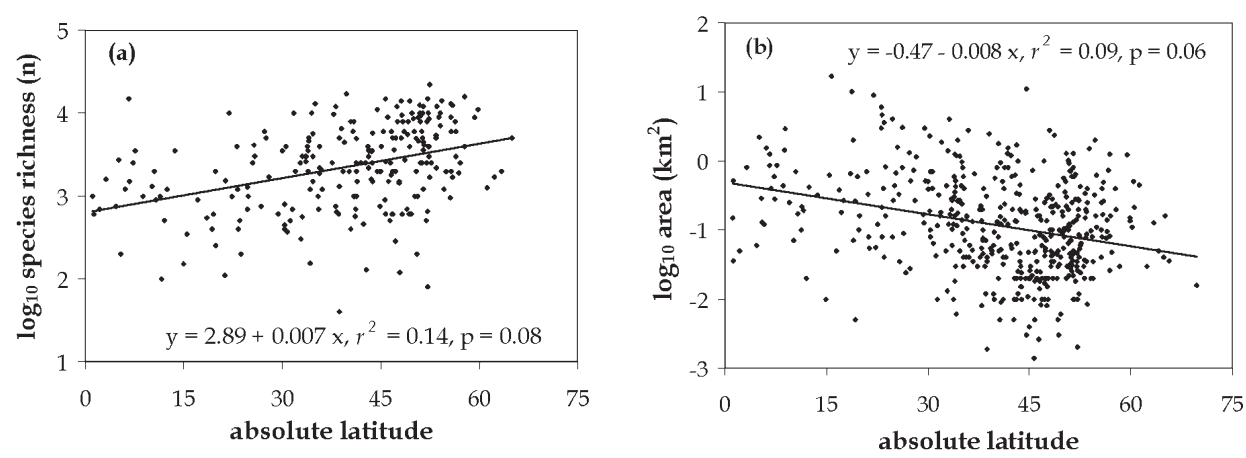

Fig. 3. Relationships between (a) species richness and absolute latitude, and (b) area and absolute latitude of botanical gardens worldwide.
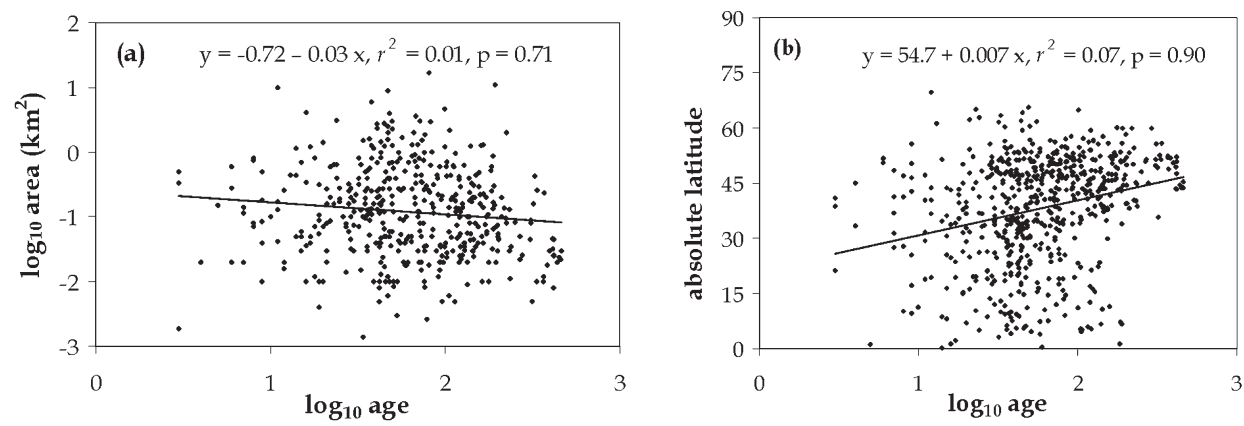

Fig. 4. Relationships between (a) area and age, and (b) absolute latitude and age (in years) of botanical gardens worldwide.

\section{Discussion}

With their ex or in situ conservation activities, botanical gardens are living warehouses of biological diversity (Mistretta et al. 1991; Melzheimer 1996; Ingram 1999). They show a wide range of number of species in their living collections (Fig. 1a), high variability in their areas (Fig. 1b) and ages (Fig. 1c), as well as a widespread spatial distribution (Mamaev and Andreev 1996; Wyse Jackson 2001; He 2002). Botanical gardens are planted, weeded, pruned and tended, but so are other artificial ecosystems. They are thus one of the many examples of ecosystems present in urbanized areas (Tait et al. 2005; Schwartz et al. 2006; Wania et al. 2006). They can be considered as a plant meta-population network where most exchanges are controlled by man. It would be interesting to know whether the exchanges of propagating material and expertise between botanical gardens in the world is best modelled in terms of a random, smallworld or scale-free network, as network structure may have an influence on the viability 
of plant meta-populations grown in botanical gardens (Jeger et al. 2007). The analyses presented here suggest that also the number of plant species in these managed ecosystems, to a first approximation, can be described in terms of a relatively small number of large-scale patterns.

The botanical gardens of the world are no exception to the rule that larger ecosystems are able to support more species than smaller ones (see Introduction). The slope of the relationship for the botanical gardens of the world $(+0.35$ when controlling for age and latitude) is at the upper end of the range in the slopes of species-area relationships commonly reported (MacArthur and Wilson 1967). Since this slope is shallower than 1 (i.e. the increase in the number of species with increasing botanical garden area is less than proportional), the density of species per unit area is higher for smaller botanical gardens (there is a negative species density-area relationship). Botanical gardens are thus an exception to the rule that the influence of people on biodiversity in urbanized ecosystems becomes more negative the smaller the study grain (Pautasso 2007). The positive species-area relationship in botanical gardens (Fig. 2a) is compatible with the two main mechanisms that have been suggested to be responsible for species-area relationships: (i) larger botanical gardens may contain more habitat types, thus enabling the cultivation of a greater number of species and (ii) larger botanical gardens may be able to cultivate species with a higher number of individuals, thus reducing the likelihood of species loss. It must be added that a larger area may be positively correlated with a larger budget of botanical garden. This may enable the collection of more species, the reintroduction of those which died, and a larger working force to manage the garden.

A second result expected from what often happens in nature is the positive correlation of a botanical garden's age with its species richness (Fig. 2b). The proportion of variance in species richness of botanical gardens explained by age is four times the one explained by area. This is further evidence for the importance of time in shaping community structure (Halpern and Spies 1995; Guariguata et al. 1997; Whittaker 2000; Sheil 2001), even in non-natural ecosystems. Older botanical gardens (i) have had more time to accumulate species in their collections and to adapt the garden's environment to them, (ii) have a longer experience in maintaining the garden and in minimizing the competition between plants, and (iii) may have established more plant or seed exchange programs with other gardens. Conversely, younger botanical gardens may still need time to fill the available space with additional acquisitions and to adjust the management of their collections to their species' requirements.

Botanical gardens reverse the commonly observed decrease of species richness with increasing latitude (Fig. 3a). This pattern may be the consequence of the absence of botanical gardens older than ca. 200 years in the tropics (Fig. 4b), given that older gardens show a higher number of species (Fig. 2b). Since larger botanical gardens tend to have a higher species richness (Fig. 2a), new botanical gardens in tropical regions should be established over sufficiently large areas. There are nevertheless reasons to believe that a reversal of the trend observed along the latitudinal gradient for the cultivated species richness of botanical gardens may not happen easily. Indeed, botanical gardens in the tropics generally benefit from much fewer resources than their counterparts in the developed (temperate and boreal) world. Even if the pool of regional plant species from which they can collect species for their living collections is higher, tropical botanical gardens may have often to limit their displays to plants of local provenance. This may be caused by the costs of collecting taxa from other regions or continents, and of maintaining species not adapted to the local environment. In fact, 
the positive worldwide latitudinal gradient observed can be partly due to the energetic inputs in botanical gardens at higher latitude where heated glasshouses ensure a climatic control and the possibility to cultivate tropical plants in a harsh climate. Furthermore, the introduction of species outside their distributional range has fallen into disrepute nowadays (Henderson et al. 2006). Today, botanical gardens commit themselves to contain the spread of invasive plant species (Havens et al. 2006). But an important part of the collections of botanical gardens at higher latitude are historical collections that date from the time when collecting plants from other continents was fashionable.

Because of various legal requirements, it is becoming more and more difficult for botanical gardens of Northern latitudes to obtain plant species from the Tropics, which implies that the study and conservation of tropical plant species diversity might become more and more restricted to botanical gardens in tropical regions. It follows that tropical botanical gardens should be allocated more funds for their conservation activities. The mismatch between the latitudinal gradient in plant species richness in the natural environment and in botanical gardens goes hand in hand with the lower Gross Domestic Product of countries at tropical latitudes (Fisher and Christopher 2007; Miller and Diamond 2006). For historical reasons, botanical gardens have been in many cases located in Northern Europe, which is for climatic reasons a region of relatively low plant species diversity (Reid 1935; Adams and Woodward 1989; Huntley 1993; Barthlott et al. 1999; Maunder et al. 2001). The spatial non-coincidence of the majority of botanic gardens and of the hotspots of plant diversity has not developed in a planned way, and no consideration was given to the only recently arisen issue of potential runaway global climate warming (Walther 2004; Ohlemüller et al. 2006; Wilby and Perry 2006). Botanical gardens may well play a key role in facilitating the migration of plant species made necessary by future global change (Pearson 2006). But in the $21^{\text {st }}$ century, given that botanical gardens are essential tools for the conservation of plant biodiversity, there is also a need for a migration and propagation of botanical activity towards hotspots of biodiversity in the tropics (Holdgate 1993; Crawley 1997; Miller et al. 2004; Pinheiro et al. 2006).

Botanical gardens are of course much more worth than the number of species they harbour, given their conservation, research and educational activities (Hyams and MacQuitty 1969; Ashton 1988; Soderstrom 2001; Maunder et al. 2004; Dosmann 2006; Havens et al.2006). Many botanical gardens are also major public and tourist attractions. They provide inspiration and relaxation to visitors from their surrounding regions and, for the largest and most famous gardens, from all over the world (Garrod et al. 1993; Kohleppel et al. 2002; Lindemann-Matthies and Bose 2007). The latest figures per year are of 3000000 visitors at the Royal Botanic Gardens in Sydney, Australia; 800 000 visitors at the Chicago Botanical Gardens, US and 700000 visitors at the Royal Botanic Gardens in Edinburgh, UK. The relationships established between species richness, age, area and geographical location are general patterns which should not be used to criticize the management of particular botanical gardens. Relatively speciespoor botanical gardens are still much species-richer than their immediate surroundings and carry out important scientific, educational and recreational functions no matter how many species or taxa they have, and how large and old they are.

However, for many botanical gardens the fundamental information of how many (and which) species are present or cultivated inside their boundaries is lacking or not easily obtainable. This may be due to the difficulty in distinguishing between ornamental varieties and species, to the fluctuation of the number of species in the 
collections with the years or seasons, and to the sheer amount of work that needs to be done to keep up-to-date the records of living collections of botanical gardens with thousands of species. One problem is that many botanical gardens still do not have a web-site or do not use a proper database to manage their collections. This means that many of the figures about species (taxa, varieties) which are cultivated in a botanical garden need to be taken and interpreted with caution. The synergies between botanical gardens throughout the world and with scientists and conservationists would benefit from a more coordinated management of their collections data (Dosmann 2006; Pereira and Cooper 2006; Tankersley 2006).

\section{Zusammenfassung}

Botanische Gärten leisten einen wesentlichen Beitrag zur Aufklärung, Erforschung und Erhaltung der botanischen Vielfalt, doch über deren eigene Artenvielfalt ist wenig bekannt. Wir haben anhand einer umfangreichen Stichprobe von botanischen Gärten in 124 Ländern untersucht, wie deren Artenzahl mit der Größe, dem Alter und der geographischen Breite zusammenhängt. Die Ergebnisse zeigen, dass auch in diesen künstlichen Ökosystemen die Artenzahl typische großflächige Muster aufweist. Wir fanden eine signifikante Zunahme der Artenzahl mit zunehmender Fläche und Alter der Gärten, was den in natürlichen Ökosystemen beobachteten Zusammenhängen entspricht. Die Artenzahl nahm aber ebenfalls mit zunehmendem Breitengrad zu, anders als in natürlichen Ökosystemen. Diese Abweichung könnte durch die Verwendung geheizter Schauhäuser in höheren Breiten, die Seltenheit von älteren botanischen Gärten in den Tropen und die Armut der Entwicklungsländer, wo viele Zentren der Pflanzenbiodiversität liegen, erklärt werden. Diese Feststellung hebt die Notwendigkeit einer stärkeren Bereitstellung von finanziellen Mitteln für botanische Gärten in artenreichen Gegenden hervor. Wünschenswert wäre ebenfalls eine vermehrte Zusammenarbeit zwischen botanischen Gärten beim Datenmanagement.

Thanks be to generations of botanists for their work, to botanical gardens which posted information on the web, to the many people who kindly answered queries (see Supplementary Information online), to M. Dominguez Castro, A. Golovanova, S. Höschele, S. Leach, C. Machado, K. Maehara and L. Scobczyk for help with foreign languages, to R. Caramiello, K.J. Gaston, O. Holdenrieder, Ch. Körner, M. Jeger, M. SchererLorenzen and P.S. White for insights and discussions, and to G. Aas, S. Güsewell, O. Holdenrieder, D. Liggins, R.J. Whittaker and two anonymous reviewers for helpful comments on a previous version of the draft.

\section{References}

Adams J.M. and Woodward F.I. 1989. Patterns in tree species richness as a test of the glacial extinction hypothesis. Nature 339: $699-701$

Ashton P.S. 1988. Conservation of biological diversity in botanical gardens. In: Wilson E.O. and Peter R.M. (eds.). Biodiversity. National Academy Press, Washington, D.C., 269 - 278.

Barthlott W., Biedinger N., Braun G., Feig F., Kier G. and Mutke J. 1999. Terminological and methodological aspects of the mapping and analysis of global biodiversity. Acta Bot. Fenn. 162: $103-110$.

Connor E.F. and McCoy E.D. 1979. Statistics and biology of the species-area relationship. Am. Nat. 113: $791-833$. 
Crawley M.J. 1997. Biodiversity. Chap. 19. In: Crawley M.J. (ed.). Plant ecology. $2^{\text {nd }}$ ed. Blackwell Scientific Publications, Oxford, 595 - 632.

Crawley M.J. and Harral J.E. 2001. Scale dependence in plant biodiversity. Science 291: 864 868.

Currie D.J. 1991. Energy and large-scale patterns of animal-species and plant-species richness. Am. Nat. 137: 27 - 49.

Dosmann M.S. 2006. Research in the garden: averting the collections crisis. Bot. Rev. 72: 207 234.

Fisher B. and Christopher T. 2007. Poverty and biodiversity: measuring the overlap of human poverty and the biodiversity hotspots. Ecol. Econ. 62: 93 - 101.

Frankel O.H., Brown A.H.D. and Burdon J.J. 1995. The conservation of plant biodiversity. Cambridge University Press, Cambridge.

Garrod G., Pickering A. and Willis K. 1993. The economic value of botanical gardens - a recreational perspective. Geoforum 24: 215 - 224.

Gaston K.J. 2000. Global patterns in biodiversity. Nature 405: $220-227$.

Gaston K.J. 2004. Macroecology and people. Basic Appl. Ecol. 5: 303 - 307.

Guariguata M.R., Chazdon R.L., Denslow J.S., Dupuy J.M. and Anderson L. 1997. Structure and floristics of secondary and old-growth forest stands in lowland Costa Rica. Plant Ecol. 132: $107-120$.

Halpern C.B. and Spies T.A. 1995. Plant-species diversity in natural and managed forests of the Pacific-Northwest. Ecol. Appl. 5: 913 - 934.

Havens K., Vitt P., Maunder M., Guerrant E.O. and Dixon K. 2006. Ex situ plant conservation and beyond. BioScience 56: $525-531$.

He S.-A. 2002. Fifty years of botanical gardens in China. Acta Bot. Sinica 44: 1123-1133.

Henderson S., Dawson T.P. and Whittaker R.J. 2006. Progress in invasive plants research. Prog. Phys. Geogr. 30: 25 - 46.

Heyd T. 2006. Thinking through botanic gardens. Envir. Values 15: $197-212$.

Heywood V.H. 1990. Botanical gardens and the conservation of plant resources. Impact Sci. Soc. 40: $121-132$.

Hillebrand H. 2004. On the generality of the latitudinal diversity gradient. Am. Nat. 163:192 211.

Holdgate M.W. 1993. Nature conservation: the role of botanical gardens - introduction. Boissiera 47: 28 - 31 .

Huntley B. 1993. Species-richness in north-temperate zone forests. J. Biogeogr. 20: 163 - 180.

Hyams E. and MacQuitty W. 1969. Great botanical gardens of the world. Macmillan, New York.

Ingram D.S. 1992. Towards an informed public. Proc. Royal Soc. Edinburgh B 99: 121 - 134.

Ingram D.S. 1999. Biodiversity, plant pathogens and conservation. Plant Path. 48: 433 - 442.

Jeger M.J., Pautasso M., Holdenrieder O. and Shaw M.W. 2007. Modelling disease spread and control in complex networks: implications for plant sciences. New Phytol. 174: 279 - 297.

Kier G., Mutke J., Dinerstein E., Rucketts T.H., Küper W., Kreft H. and Barthlott W. 2005. Global patterns of plant diversity and floristic knowledge. J. Biogeogr. 32: 1107-1116.

Kohleppel T., Bradley J.C. and Jacob S. 2002. A walk through the garden: can a visit to a botanic garden reduce stress? Horttechnology 12: 489 - 492.

Kühn I. 2007. Incorporating spatial autocorrelation may invert observed patterns. Div. \& Distrib. 13: 66 - 69.

Lawton J.H. 1999. Are there general laws in ecology? Oikos 84: $177-192$.

Leadlay E., Willison J. and Wyse Jackson P.S. 2006. Taxonomy: the framework for botanic gardens in conservation. In: Leadlay E. and Jury S. (eds.). Taxonomy and plant conservation. Cambridge University Press, Cambridge, $274-293$.

Leigh E.G. Jr., Davidar P., Dick C.W., Puyravaud J.-P., Terborgh J., Steege H. ter and Wright S.J. 2004. Why do some tropical forests have so many species of trees? Biotropica 36: $447-473$.

Lindemann-Matthies P. and Bose E. 2007. Species richness, structural diversity and species composition in meadows created by visitors of a botanical garden in Switzerland. Lands. Urb. Plan. 79: 298 - 307. 
MacArthur R.H. and Wilson E.O. 1967. The theory of island biogeography. Princeton University Press, Princeton, NJ.

Mamaev S.A. and Andreev L.N. 1996. Importance of Russian botanical gardens for preservation of floristic diversity. Russian J. Ecol. 27: 432 - 437.

Marris E. 2006. Gardens in full bloom. Nature 440: 860 - 863.

Maunder M. 1994. Botanic gardens: future challenges and responsibilities. Biodiv. Conserv. 3: $97-103$.

Maunder M., Higgens S. and Culham A. 2001. The effectiveness of botanic garden collections in supporting plant conservation: a European case study. Biodiv. Conserv. 10: 383 - 401.

Maunder M., Guerrant E.O. Jr., Havens K. and Dixon K.W. 2004. Realizing the full potential of ex situ contributions to global plant conservation. In: Guerrant E.O., Havens K. and Maunder M. (eds.). Ex situ plant conservation: supporting species survival in the wild. Island Press, Washington, D.C., $389-418$.

Melzheimer V. 1996. Die Aufgaben eines Botanischen Gartens im Wandel der Zeiten. Der Tropenlandwirt 97: $113-125$.

Miller B., Conway W., Reading R.P., Wemmer C., Wildt D., Kleiman D., Monfort S., Rabinowitz A., Armstrong B. and Hutchins M. 2004. Evaluating the conservation mission of zoos, aquariums, botanical gardens, and natural history museums. Conserv. Biol. 18: 86 93.

Miller S. and Diamond J. 2006. Social sciences: a New World of differences. Nature 441: 411 412.

Mistretta O., Rieseberg L.H. and Elias T.S. 1991. Botanical gardens and the preservation of biological diversity. Evol. Trends Plants 5: $19-22$.

Myers N. 1988. Threatened biotas: 'hot-spots' in tropical forests. Environmentalist 8:187 - 208.

Novotny V., Basset Y., Miller S.E., Kitching R.L., Laidlaw M., Drozd P. and Cizek L. 2004. Local species richness of leaf-chewing insects feeding on woody plants from one hectare of a lowland rainforest. Cons. Biol. 18: 227 - 237.

Ohlemüller R., Gritti E.S., Sykes M.T. and Thomas C.D. 2006. Quantifying components of risk for European woody species under climate change. Glob. Change Biol. 12: 1788 - 1799.

Pärtel M. and Zobel M. 1999. Small-scale plant species richness in calcareous grasslands determined by the species pool, community age and shoot density. Ecography 22:153 - 159 .

Pautasso M. and Gaston K.J. 2006. A test of the mechanisms behind avian generalized individuals - area relationships. Glob. Ecol. Biogeogr. 15: 303-317.

Pautasso M. 2007. Scale dependence of the correlation between human population presence and vertebrate and plant species richness. Ecol. Lett. 10: 16 - 24.

Pearson R.G. 2006. Climate change and the migration capacity of species. Trends Ecol. Evol. 21: $111-113$.

Pereira H.M. and Cooper H.D. 2006. Towards the global monitoring of biodiversity change. Trends Ecol. Evol. 21: 123 - 129.

Pinheiro M.H.O., Almeida de Neto L.C. and Monteiro R. 2006. Urban areas and isolated remnants of natural habitats: an action proposal for botanical gardens. Biodiv. Conserv. 15: $2747-2764$.

Reid E.M. 1935. British floras antecedent to the Great Ice Age. Discussion on the origin and relationship of the British Flora. Proc. Royal Soc. London B 118: 197.

Rohde K. 1992. Latitudinal gradients in species-diversity - the search for the primary cause. Oikos 65, 3: $514-527$.

Scheiner S.M. and Rey-Benayas J.M. 1994. Global patterns of plant diversity. Evol. Ecol. 8: $331-347$

Schwartz M.W., Thorne J.H. and Viers J.H. 2006. Biotic homogenization of the California flora in urban and urbanizing regions. Biol. Conserv. 127: 282 - 291.

Sheil D. 2001. Long-term observations of rain forest succession, tree diversity and responses to disturbance. Plant Ecol. 155: 183 - 199.

Soderstrom M. 2001. Recreating Eden: a natural history of botanical gardens. Montreal, Vehicule Press. 
Tait C.J., Daniels C.B. and Hill R.S. 2005. Changes in species assemblages within the Adelaide Metropolitan Area, Australia, 1836 - 2002. Ecol. Appl. 15: 346 - 359.

Tankersley B. 2006. Plant databases linked for botanists and gardeners. Nature 441: 574.

Terrell J.E. 2006. Human biogeography: evidence of our place in nature. J. Biogeogr. 33: 2088 2098.

Tomasi L.T. 2005. The origins, function and role of the botanical garden in sixteenth- and seventeenth-century Italy. Stud. Hist. Gard. Design. Landsc. 25: 103 - 115.

Waide R.B., Willig M.R., Steiner C.F., Mittelbach G., Gough L., Dodson S.I., Juday G.P. and Parmenter R. 1999. The relationship between productivity and species richness. Ann. Rev. Ecol. Syst. 30: $257-300$.

Walther G.R. 2004. Plants in a warmer world. Persp. Plant Ecol. Evol. Syst. 6: 169 - 185

Wania A., Kuhn I. and Klotz S. 2006. Plant richness patterns in agricultural and urban landscapes in Central Germany - spatial gradients of species richness. Landsc. Urb. Plan. 75: $97-110$.

Whittaker R.J. 2000. Scale, succession and complexity in island biogeography: are we asking the right questions? Glob. Ecol. Biogeogr. 9: 75 - 85.

Wilby R.L. and Perry G.L.W. 2006. Climate change, biodiversity and the urban environment: a critical review based on London, UK. Prog. Phys. Geogr. 30: 73 - 98.

Wyse Jackson P.S. 1999. Experimentation on a large scale: an analysis of the holdings and resources of Botanic Gardens. Bot. Gard. Cons. News 3, 3: 27 - 32.

Wyse Jackson P.S. 2001. An international review of the ex situ plant collections of the botanic gardens of the world. Bot. Gard. Cons. News 3, 6:22 - 33.

\section{Electronic Appendix}

Appendix 1. List of people who kindly answered queries.

This Appendix is available online at http://www.birkhauser.ch/BH 